\title{
KAJIAN TERHADAP KEBIJAKAN PEMERINTAH DALAM PEMBERIAN SUBSIDI DI SEKTOR PERUMAHAN
}

\author{
Dora Kusumastuti \\ Fakultas Hukum Universitas Slamet Riyadi Surakarta \\ Email : dora.kusumastuti@yahoo.co.id
}

\begin{abstract}
The purpose of this research is to find out the subsidy policy developments in the housing field in Indonesia, and to know the obstacles that hinder the implementation of subsidized housing in Indonesia. This research is a normative law, namely the research that is done by examining secondary data (library) consists of: primary law materials; secondary law material. In a normative law research, data have been collected, either through an inventory of primary law materials and investigation of secondary materials, conducted content analysis which is then processed into premises- general premise of common norms in the regulation of subsidy in the housing field. Further, analyzed deductively using syllogism thought patterns composed of two statements (major premise and minor premise) and a conclusion. Conclusions: 1) the provision of subsidy to lowincome people is expected to bring people, especially low-income people to own a home; 2) low levels of uptake for subsidized housing.
\end{abstract}

Key Word: Housing Policy, Housing Subsidy, Housing Owner Loan.

\begin{abstract}
Abstrak
Tujuan penelitian ini adalah untuk mengetahui perkembangan kebijakan subsidi di bidang perumahan di Indonesia, dan untuk mengetahui kendala-kendala yang menghambat pembangunan perumahan bersubsidi di Indonesia. Penelitian ini merupakan penelitian hukum normatif, yaitu penelitian yang dilakukan dengan cara meneliti data sekunder (pustaka) terdiri dari :bahan hukum primer; bahan hukum sekunder. Dalam penelitian hukum normatif, data yang telah terkumpul, baik melalui inventarisasi bahan-bahan hukum primer maupun penyelusuran bahan sekunder, dilakukan content analysis yang kemudian diolah menjadi premis- premis umum tentang norma-norma umum dalam peraturan subsidi di bidang perumahan.Selanjutnya dianalisis secara deduktif dengan mempergunakan pola berfikir silogisme yang tersusun dari dua buah pernyataan (premis mayor dan premis minor) dan sebuah kesimpulan. Kesimpulan:1)pemberian subsidi terhadap masyarakat berpenghasilan rendah ini diharapkan akan mewujudkan masyarakat khususnya masyarakat berpenghasilan rendah untuk memiliki rumah; 2) rendahnya tingkat serapan terhadap perumahan bersubsidi.
\end{abstract}

Kata kunci : Kebijakan perumahan, subsidi perumahan, 


\section{A. Pendahuluan}

Rumah sebagai salah satu kebutuhan primer manusia setelah pangan dan sandang harus terpenuhi. Setelah terpenuhinya kebutuhan primer sebagai kebutuhan pokok manusia, baru manusia memenuhi kebutuhan sekunder dan kebutuhan tertier. Fungsi rumah selain sebagai pelindung dari segala cuaca dan gangguan alam juga makluk hidup lainnya, rumah juga berfungsi sebagai pusat pendidikan keluarga, pusat persemaian budaya dan peningkatan kualitas generasi muda suatu bangsa. Pemenuhan terhadap kebutuhan rumah semakin sulit terpenuhi, seiring dengan pertumbuhan penduduk yang pesat mengakibatkan harga tanah semakin tinggi. Petumbuhan penduduk yang terpusat di daerah perkotaan, rawan memunculkan daerah kumuh baik di bantaran rel kereta api, maupun bantaran sungai.

Salah satu upaya untuk mendorong terhadap pemenuhan kebutuhan terhadap rumah, diperlukan suatu penyediaan perumahan yang disediakan baik oleh pemerintah maupun swasta. Perumahan tersebut diklasifikasikan menurut tipe dari rumah dengan memperhatikan tingkat keterjangkauan daya beli oleh masyarakat Indonesia(Undang-Undang Nomor 1 Tahun 2011 tentang Perumahan dan Kawasan Permukiman).

Pasal 28 H Ayat (1) Undang-Undang Dasar 1945 menyatakan bahwa Setiap orang berhak hidup sejahtera lahir dan batin, bertempat tinggal, dan mendapatkan lingkungan hidup yang baik dan sehat serta berhak memperoleh pelayanan kesehatan. Sesuai dengan amanat UUD1945 negara berkewajiban untuk memenuhi hak tersebut, diantaranya adalah hak mendapatkan tempat tinggal, negara mengatur tentang kebijakan mengenai perumahan dan kawasan permukiman.

Kebutuhan rumah di Indonesia setiap tahunnya terus bertambah. Berdasarkan data dari Real Estate Indonesia (REI), total kebutuhan rumah per tahun bisa mencapai 2,6 juta didorong oleh pertumbuhan penduduk, perbaikan rumah rusak dan backlog atau kekurangan rumah (http://finance.detik.com). Berdasarkan data jumlah penduduk Indonesia 
lebih kurang 241 juta jiwa dengan angka pertumbuhan penduduk 1,3 \% per tahun. Jumlah rata-rata orang per Kepala Keluarga (KK) lebih kurang 4,3 jiwa.Dengan perhitungan jumlah kebutuhan rumah 241 juta $x$ 1,3\% = 4,3 juta. Sehingga setiap tahunnya dibutuhkan 728.604 unit rumah per tahun atau jika dibulatkan menjadi 729 ribu unit rumah pertahun. Selain itu, data BPS juga menyebutkan jumlah rumah di Indonesia mencapai angka 49,3 juta unit. Dari jumlah itu 3\%-nya perlu diperbaiki karena rusak sehingga jumlah rumah yang harus direhabilitasi mencapai 1.479.000 unit berasal dari perhitugnan 49,3 juta x 3\%.

Banyaknya kebutuhan rumah di Indonesia, sebagaimana yang terjadi pada masyarakat dunia, terutama pada masyarakat perkotaan, dengan populasi penduduknya yang besar, sehingga memerlukan upaya pemerintah untuk menangani permasalahan perumahan di tenggah berbagai kendala seperti keterbatasan lahan perumahan (Koko Hernawanan,2011:15).Tingginya kebutuhan terhadap rumah mengakibatkan semakin tingginya harga rumah. Harga rumah yang tinggi menjadikan susahnya mewujudkan impian memiliki rumah, khususnya bagi masyarakat berpenghasilan rendah.

Berdasarkan Pasal 1 ayat (3) Undang-Undang Dasar 1945 bahwa Indonesia adalah negara hukum. Negara hukum adalah negara yang mendasarkan segala sesuatu berdasarkan pada hukum. Pasal 33 UndangUndang Dasar 1945 menyiratkan makna bahwa Indonesia adalah negara welfare state atau negara kesejahteraan. Konsep negara kesejahteraan (welfare state) pada era globalisasi dan berkembangnya faham kapitalisme yang menyerahkan segala sesuatu kepada mekanisme pasar menjadi suatu hambatan tersendiri dalam mewujudkan suatu negara yang sejahtera. Welfare state oleh Ramesh Mishra, Lawrence Fridman, dan Jan M Boekman (Djauhari, 2006:16) bahwa titik berat welfare state adalah pada tanggung jawab negara untuk kesejahteraan warga negara terhadap pemenuhan kebutuhan dasar hidup manusia, pelayanan sosial, dan intervensi terhadap pasar. Bahwa welfare state sebagai suatu tanggung 
jawab negara terhadap kesejahteraan warga negaranya. Dalam hal tersedianya kebutuhan terhadap rumah, pemerintah memberikan subsidi terhadap masyarakat berpenghasilan rendah (MBR). Masyarakat berpenghasilan rendah (MBR) adalah masyarakat yang memiliki pendapatan kurang. Subsidi KPR oleh pemerintah merupakan upaya untuk meningkatkan kepemilikan rumah terhadap masyarakat berpenghasilan rendah, di tenggah tingginya harga rumah. Undang-Undang Nomor 4 Tahun 1992 Tentang Perumahan dan Permukiman sudah tidak sesuai dengan perkembangan dan kebutuhan perumahan dan permukiman yang layak dan terjangkau dalam lingkungan yang sehat, aman, serasi, dan teratur sehingga diganti dengan Undang-Undang Nomor 1 Tahun 2011 Tentang Perumahan dan Kawasan Permukiman (Jawa Pos,3 Januari 2012).

Salah satu hal khusus yang diatur dalam undang-undang ini adalah keberpihakan negara terhadap masyarakat berpenghasilan rendah. Pemerintah dan/atau pemerintah daerah wajib memenuhi kebutuhan rumah bagi masyarakat berpenghasilan rendah dengan memberikan kemudahan pembangunan dan perolehan rumah melalui program perencanaan pembangunan perumahan secara bertahap dan berkelanjutan. Kemudahan pembangunan dan perolehan rumah bagi masyarakat berpenghasilan rendah itu, dengan memberikan kemudahan, berupa pembiayaan, pembangunan prasarana, sarana, dan utilitas umum, keringanan biaya perizinan, bantuan stimulan, dan insentif fiskal. Penelitian ini untuk mengetahui perkembangan subsidi perumahan di Indonesia, dan mengetahui kendala yang dihadapi dalam pembangunan rumah bersubsidi, yang dirumuskan dalam rumusan masalah bagaimanakah perkembangan kebijakan subsidi di bidang perumahan di Indonesia dan kendala apa sajakah yang menghambat pembangunan perumahan bersubsidi

\section{B. Metode Penelitian}

Penelitian ini merupakan penelitian hukum normatif, yaitu penelitian yang dilakukan dengan cara meneliti data sekunder (pustaka). Data sekunder terdiri dari bahan hukum primer yang terdiri dari UU 1945, 
Peraturan perundangan di bidang Perumahan bersubsidi. Bahan hukum sekunder yang terdiri dari literatur yang menunjang, baik jurnal maupun hasil penelitian. Dalam penelitian hukum normatif, data yang telah terkumpul, baik melalui inventarisasi bahan-bahan hukum primer maupun penyelusuran bahan sekunder, dilakukan content analysis yang kemudian diolah menjadi premis- premis umum tentang norma-norma umum dalam peraturan subsidi di bidang perumahan. Selanjutnya dianalisis secara deduktif yaitu suatu penalaran yang berpangkal pada peristiwa umum, yang kebenarannya telah diketahui atau diyakini, dan berakhir pada suatu kesimpulan yang bersifat lebih khusus, sehingga diperoleh norma-norma khusus tentang pemilikan rumah (KPR) bersubsidi. Penarikan simpulan secara deduktif mempergunakan pola berfikir silogisme yang tersusun dari dua buah pernyataan (premis mayor dan premis minor) dan sebuah kesimpulan.

\section{Hasil Penelitian dan Pembahasan}

\section{Perkembangan Kebijakan Subsidi di Bidang Perumahan di Indonesia.}

Ketika suatu bangsa memasuki tahap negara kesejahteraan (welfare state) tuntutan terhadap intervensi pemerintah melalui pembentukan hukum yang melindunggi pihak yang lemah sanggat kuat, termasuk untuk menciptakan kesejahteraan dimasyarakat(Inosensius Samsul, 2004:23). Melalui Undang-Undang Nomor 4 Tahun 1992 tentang Perumahan dan Permukiman, memberikan harapan yang besar terhadap masyarakat berpenghasilan rendah (MBR) untuk mendapatkan rumah. Sesuai dengan amanat Undang-Undang Nomor 4 Tahun 1992 Tentang Perumahan dan Permukiman pemerintah mengulirkan kebijakan pemberian subsidi perumahan.

Subsidi perumahan adalah suatu kredit yang diperuntukan kepada masyarakat berpenghasilan menengah ke bawah dalam rangka memenuhi kebutuhan perumahan atau perbaikan rumah yang telah 
dimiliki. Bentuk subsidi yang diberikan berupa: subsidi selisih bunga, penambahan dana pembangunan, memperbaiki rumah.

Pada era tahun 1980 dan era 1990-an kejayaan PERUMNAS dan BTN (Bank Tabungan Negara) impian rakyat untuk memiliki rumah dapat terwujud. Pada tahun 1992-1998 BTN dengan Perumnas mampu menyediakan 50\% perumahan nasional disediakan dengan Perumnas. Perumnas ini disediakan dalam rumah sederhana (RS) dan rumah sangan sederhana (RSS) serempak diberbagai kota di Indonesia(Reinald Kasali,2013:1). Program Kredit Pemilikan Rumah (KPR) Bersubsidi merupakan bagian dari inisiatif pemerintah yang telah dicanangkan sejak 2003 melalui “Gerakan Nasional Pembangunan Sejuta Rumah” dan “Program 1000 Tower Rumah Susun Sederhana” yang ditujukan bagi masyarakat dengan daya beli rendah. Subsidi yang diberlakukan didasarkan pada dua hal, yakni berupa subsidi uang muka dan subsidi selisih bunga.Maka pemerintah menjalin kerjasama dengan pihak perbankan dalam hal pemberian kredit pemilikan rumah (KPR) bersubsidi bagi masyarakat berpenghasilan rendah, sebagai salah satu usaha untuk meningkatan kesejahteraan dan taraf hidup masyarakat di Indonesia (http://elib.unikom.ac.id).

Upaya untuk mendorong terhadap kepemilikan rumah dilaksanakan oleh pemerintah melalui kebijakan pemberian subsidi perumahan. Hal ini diwujudkan dalam Peraturan Menteri Negara Perumahan Rakyat RI Perumahan Rakyat Nomor 05 Tahun 2005 tentang Pengadaan Perumahan dan Permukiman Dengan Dukungan Fasilitas Subsidi Perumahan Melalui KPR/KPRS Bersubsidi. Peraturan Menteri Perumahan Rakyat RI Nomor 12 Tahun 2006 tentang Perubahan Atas Peraturan Menteri Negara Perumahan Rakyat Nomor 05 Tahun 2005 tentang Pengadaan Perumahan dan Permukiman Dengan Dukungan Fasilitas Subsidi Perumahan Melalui KPR/KPRS Bersubsidi. Pada tahun 2005 melalui Peraturan Menteri Perumahan Rakyat Nomor 5 Tahun 2005 tentang Subsidi Kredit Pemilikan Rumah (KPR)/Kredit 
Pemilikan Rumah Sederhana (KPRS) diatur mengenai kebijakan pemberian subsidi perumahan bagi masyarakat yang berpenghasilan rendah dan belum memiliki hunian.

Peraturan Menteri Perumahan Rakyat Nomor 02 Tahun 2006 tentang Pemberian Pinjaman/Pembiayaan Uang Muka Kredit Kepemilikan Rumah (KPR) Bagi Pegawai Sipil memberikan kesempatan kepada Pegawai Negeri Sipil untuk mendapatkan fasilitas pembiayaan KPR melalui BAPELTARUM PNS. BAPERTARUM-PNS didirikan berdasarkan Keputusan Presiden RI Nomor 14 Tahun 1993 tentang "Tabungan Perumahan Pegawai Negeri Sipil", sebagaimana telah diubah dengan Keputusan Presiden Nomor 46 Tahun 1994.

Peraturan Menteri Negara Perumahan Rakyat RI Perumahan Rakyat Nomor 05 Tahun 2007 tentang Pengadaan Perumahan dan Permukiman dengan Dukungan Fasilitas Subsidi Perumahan Melalui KPRS/ KPRS Mikro Bersubsidi. Peraturan Menteri Perumahan Rakyat RI Nomor 08 Tahun 2008 tentang Perubahan Atas PERMENPERA Nomor 04 Tahun 2007 tentang Pengadaan Perumahan dan Permukiman Dengan Dukungan Fasilitas Subsidi Perumahan Melalui KPR Syariah Bersubsidi. Peraturan Menteri Negara Perumahan Rakyat RI Nomor 17 Tahun 2011 tentang Tata Cara Pelaksanaan Subsidi Perumahan Melalui KPRS/ KPRS Mikro Bersubsidi.

Jaminan terhadap kesejahteraan dalam sektor perumahan diatur lebih lanjut dalam Undang-Undang Nomor 1 Tahun 2011 tentang Perumahan dan Kawasan Permukiman.Dalam Undang-Undang ini negara menyatakan memiliki peran yang sangat penting dalam penyediaan dan penyelenggaraan kawasan permukiman, sehingga mampu bertempat tinggal serta menghuni rumah yang layak dan terjangkau di dalam lingkungan yang sehat, aman, harmonis, danberkelanjutan di seluruh wilayah Indonesia.Negara juga bertanggung jawab dalam menyediakan dan memberikan kemudahan perolehan rumah bagi masyarakat melalui penyelenggaraan perumahan 
dan kawasan permukiman serta keswadayaan masyarakat.Penyediaan dan kemudahan perolehan rumah tersebut merupakan satu kesatuan fungsional dalam wujud tata ruang, kehidupan ekonomi, dan sosial budaya yang mampu menjamin kelestarian lingkungan hidup sejalan dengan semangat demokrasi, otonomi daerah, dan keterbukaan dalamtatanan kehidupan bermasyarakat, berbangsa, dan bernegara.

Berdasarkan Undang-Undang Nomor 1 Tahun 2011 tentang Perumahan dan Kawasan Permukiman, Pasal 22 Ayat (3) memberikan pembatasan terhadap rumah tunggal atau deret yang dapat difasilitasi melalui KPR sejahtera tapak memiliki ukuran luas lantai rumah paling sedikit 36 (tiga puluh enam) meter persegi. Ketentuan dari pasal ini dianggap bertentangan dengan tujuan Undang-Undang Nomor 1 Tahun 2011 tentang Perumahan dan Kawasan Permukiman untuk menyediakan rumah bagi MBR. Sesuai dengan daya beli dari MBR, semakin kecil luas rumah akan semakin murah pula harga rumah sejehtera tersebut.

Pada tanggal 3 Oktober 2012 Makamah Konstitusi membatalkan ketentuan Undang-Undang (UU) Nomor 1 tahun 2011 tentang Perumahan dan Kawasan Permukiman Pasal 22 Ayat (3) yang melarang pendirian rumah tunggal/deret berukuran kurang dari $36 \mathrm{~m} 2$. Konsekwensi dari pembatalan pasal untuk minimal ukuran rumah yang bisa dibiayai dengan FLPP adalah tipe 36 (luas tanah 60m2) batal, sehingga untuk tipe kurang dari tipe 36 bisa mendapatkan subsidi melalui FLPP(http://properti.kompas.com).

Berdasarkan pemberian pola subsidi lama, dengan pemberian subsidi pada uang muka dan selisih bunga, pemerintah mengubah sistem pemberian subsidi berupapemberian fasilitas likuiditas pemilikan perumahan (FLPP) yang dituangkan dalam Peraturan Menteri Negara Perumahan RakyatNomor 13 Tahun 2012 tentang Pengadaan Perumahan Melalui Kredit/Pembiayaan Pemilikan Rumah Sejahtera Dengan Dukungan Fasilitas Likuiditas Pembiayaan Perumahan. 
Dengan meningkatnya biaya pembangunan perumahan, perlu dilakukan penyesuaian terhadap ketentuan mengenai batasan harga jual rumah yang dapat diberikan fasilitas kemudahan dalam perolehan rumah. Dalam rangka penyesuaian terhadap ketentuan mengenai batasan harga jual rumah dan meningkatkan daya beli masyarakatberpenghasilan rendah, perlu mengganti Peraturan Menteri Nomor 27 Tahun 2012 tentang Pengadaan PerumahanMelalui Kredit/Pembiayaan Pemilikan Rumah Sejahtera dengan Dukungan Fasilitas Likuiditas Pembiayaan Perumahan.Peraturan Menteri Perumahan Rakyat Nomor 3 Tahun 2014 tentang Fasilitas Likuiditas Pembiayaan Perumahan Melalui Kredit/Pembiayaan Pemilikan Rumah Sejahteramaka Peraturan Menteri Perumahan Rakyat Nomor 27 Tahun 2012 tentang Pengadaan Perumahan Melalui Kredit/Pembiayaan Pemilikan Rumah Sejahtera Dengan Dukungan Fasilitas Likuiditas Pembiayaan Perumahan dicabut dan dinyatakan tidak berlaku.

Menurut pendekatan teori kepentingan umum (public interest theories) bahwa regulasi disajikan untuk menanggapi permintaan publik akan koreksi terhadap ketidakefisienan atau ketidak layakan harga pasar. Tujuan utama dari teori ini adalah untuk melindungi masyarakat dan mewujudkan negara yang sejahtera (Y.Warella, Eprints.undip.ac.id). Pemberian subsidi pada bidang perumahan merupakan salah satu kebijakan dari pemerintah terhadap penyediaan perumahan khususnya masyarakat berpenghasilan rendah. Dari koreksi harga pasar perumahan yang sangat tinggi tidak memberikan peluang kepada masyarakat berpenghasilan rendah untuk memiliki rumah. Pemberian subsidi terhadap masyarakat berpenghasilan rendah ini diharapkan akan mewujudkan masyarakat khususnya masyarakat berpenghasilan rendah untuk memiliki rumah.

Undang-Undang Dasar 1945Pasal 28 H menyatakan "negaraberkewajiban membantu mengadakan rumah yang layak bagi rakyat Indonesia”. Dalam Undang-Undang Nomor 25 Tahun 2000 
tentang Propernasdan Undang-Undang Nomor 28 tahun 2002 tentang Bangunan Gedung Pasal 43 ayat (4) yang mewajibkan pemerintahmemberdayakan masyarakat miskin yang belum memiliki akses pada rumah. Semua arahan konstitusional tersebut bertujuan memberikan aksesibilitas rumah bagi rakyat Indonesia, terutama bagi masyarakat berpenghasilan bawah (Handa.S. Abidin, Law Library of congress).

\section{Kendala yang Menghambat Pembangunan Perumahan Bersubsidi}

Berdasarkan pada Peraturan Menteri Perumahan Rakyat Nomor 3 Tahun 2014 tentang Fasilitas Likuiditas Pembiayaan Perumahan Melalui Kredit/ Pembiayaan Pemilikan Rumah Sejahtera maka pada saat Peraturan Menteri terbaru mulai berlaku, Peraturan Menteri Perumahan Rakyat Nomor 27 Tahun 2012 tentang Pengadaan Perumahan Melalui Kredit/Pembiayaan Pemilikan Rumah Sejahtera Dengan Dukungan Fasilitas Likuiditas Pembiayaan Perumahan dicabut dan dinyatakan tidak berlaku.

Pembiayaan di berikan Kementrian Perumahan Rakyat yang dikelola oleh Pusat Pembiayaan Perumahan (PPP) dengan bank pelaksana sebagai penyedia fasilitas kredit pembiayaan perumahan dengan fasilitas likuiditas pembiayaan perumahan. Kredit/pembiayaan kepemilikan rumah sederhana sehat (KPRSh) sebagaimana dimaksud dalam Pasal 2 ayat (1) Peraturan Menteri Perumahan Rakyat Nomor 3 Tahun 2014 tentang Fasilitas Likuiditas Pembiayaan Perumahan Melalui Kredit/ Pembiayaan Pemilikan Rumah Sejahtera adalah:

a. Kredit pemilikan rumah sejahtera (KPR Sejahtera)

1) KPR sejahtera tapak;

2) KPR sejahtera syariah tapak;

3) KPR sejahtera susun; dan

4) KPR sejahtera syariah susun.

b. Kredit pemilikan rumah sejahtera murah (KPR Sejahtera Murah); 
c. Kredit pembangunan atau perbaikan rumah swadaya sejahtera (KPRS sejahtera);

d. Kredit konstruksi rumah sejahtera (KK Rumah Sejahtera); dan

e. Kredit konstruksi rumah sejahtera murah (KK Rumah Sejahtera Murah).

Rumah sejahtera tapak adalah rumah umum yang dibangun oleh orang perseorangan atau badan hukum dengan spesifikasi sama dengan rumah sederhana sebagaimana diatur dalam Keputusan Menteri Permukiman dan Prasarana Wilayah Nomor 403/KPTS/M/2002 tentang Pedoman Teknis Pembangunan Rumah Sederhana Sehat, Peraturan Menteri Negara Perumahan Rakyat Nomor 25 Tahun 2011 tentang Pedoman Penyelenggaraan Perumahan Murah, dan/atau peraturan perundang-undangan yang mengatur tentang pedoman teknis pembangunan rumah sejahtera.

Rumah sejahtera susun adalah rumah susun umum yang dibangun oleh orang perseorangan atau badan hukum dengan spesifikasi sama dengan rumah susun sederhana sebagaimana diatur dalam Peraturan Menteri Pekerjaan Umum Nomor 05/PRT/M/2007 tentang Pedoman Teknis Pembangunan Rumah Susun Sederhana Bertingkat Tinggi atau Peraturan Menteri Pekerjaan Umum Nomor 60/PRT/1992 tentang Persyaratan Teknis Pembangunan Rumah Susun.

Proses kepemilikan terhadap rumah sederhana tapak maupun rumah sederhana susun dapat diperoleh melalui kredit pemilikan rumah sejahtera, yang selanjutnya disebut KPR sejahtera, adalah kredit atau pembiayaan pemilikan rumah yang meliputi KPR sejahtera tapak dan KPR sejahtera susun yang diterbitkan oleh bank pelaksana secara konvensional maupun dengan prinsip syariah. Kredit kepemilikan rumah didukung oleh program fasilitas likuiditas pembiayaan (FLPP) yang disediakan oleh Kementerian Perumahan Rakyat.

Imbalan atas jasa layanan yang diterima oleh PPP dari bank pelaksana yang berupa suku bunga/imbal hasil atas dana program FLPP 
KPR sejahtera disebut dengan tarif KPR sejahtera. Dalam peraturan menteri sebelumnya tarif ini disebut dengan bunga yang merupakan keuntungan dari pembiayaan kredit pemilikan rumah sejahtera. Tarif tersebut diberikan oleh bank pelaksana KPR sejahtera terhadap PPP atas penyediaan dana FLPP sebesar 0,5\% pertahun.

Penyaluran dana FLPP dari PPP kepada kelompok sasaran KPR sejahtera dilakukan melalui bank pelaksana. Bank pelaksana adalah bank yang telah memiliki kerjasama dengan Kementerian Perumahan Rakyat untuk melaksanakan pembiayaan kredit pemilikan rumah sejahtera. Penyaluran dana sebagaimana dimaksud pada ayat (1) dilakukan dengan menggunakan pola executing yaitu pola penyaluran dengan risiko ketidaktertagihan dana FLPP ditanggung oleh Bank Pelaksana. Dana FLPP yang disalurkan oleh bank pelaksana kepada kelompok sasaran KPR sejahtera dalam rangka kepemilikan rumah dikenakan tarif KPR sejahtera sesuai dengan ketentuan peraturan menteri yang menyelenggarakan urusan pemerintahan di bidang keuangan.

Dana KPR sejahtera merupakan gabungan antara dana FLPP dan dana bank pelaksana. Gabungan antara dana FLPP dan dana bank pelaksana dengan proporsi tertentu dilakukan untuk menerbitkan KPR sejahtera dengan tingkat suku bunga kredit/marjin pembiayaan yang terjangkau dan bersifat tetap selama jangka waktu kredit/pembiayaan.

Penentuan proporsi KPR ditetapkan oleh menteri berdasarkan tarif KPR sejahtera dan kondisi perekonomian. Proporsi sebagaimana dicantumkan dalam perjanjian kerjasama operasional antara PPP dengan bank pelaksana. Operasional pembiayaan kredit pemilikan rumah sejahtera dibagi dengan proporsi sebagai berikut: porsi dana FLPP sebesar 75\% dari KPR Sejahtera; dan porsi dana bank pelaksana sebesar 25\% dari KPR sejahtera. Dana FLPP berasal dari PPP kepada bank pelaksana dikenakan tarif KPR sejahtera sebesar 0,5\% (nol koma lima persen) per tahun. Dana FLPP disalurkan bank pelaksana dengan 
jangka waktu paling lama 20 (dua puluh) tahun. Dana FLPP tersebut disalurkan PPP kepada MBR melalui bank pelaksana menggunakan pola executing dimana pola penyaluran dengan risiko ketidaktertagihan dana FLPP ditanggung oleh bank pelaksana. Besarnya tarif yang dikenakan PPP kepada bank pelaksana terhadap KPR sejahtera sebesar 0,5\% (nol koma lima persen) per tahun. Disalurkan bank pelaksana dengan jangka waktu paling lama 20 (dua puluh) tahun.

Kelompok sasaran pengadaan perumahan melalui kredit/pembiayaan pemilikan rumah sejahtera :

a. Kelompok sasaran KPR sejahtera untuk KPR sejahtera tapak dan KPR sejahtera syariah tapak adalah MBR dengan penghasilan tetap maupun tidak tetap paling banyak Rp4.000.000,00 (empat juta rupiah) per bulan.

b. Kelompok sasaran KPR sejahtera untuk KPR sejahtera susun dan KPR sejahtera syariah susun adalah MBR dengan penghasilan tetap maupun tidak tetap paling banyak Rp7.000.000,00 (tujuh juta rupiah) per bulan.

Tingkat serapan kredit pemilikan rumah di Indonesia tergolong masih sangat rendah. Tahun 2013 besaran kredit pemilikan rumah (KPR) adalah Rp280 triliun atau 2,8 persen terhadap total produk produk domestik bruto nasional Rp10.000 triliun. Rasio KPR terhadap PDB nasional Indonesia jauh di bawah Tailand 11 persen, Tiongkok 16 persen, dan Malaysia 29 persen(Kompas, 26 April 2014). Di negara Malaysia melalui skim rumah pertamaku (SRP) yang diberlakukan mulai tahun 2011 oleh Kerajaan Malaysia untuk membantu golongan kaum muda yang baru bekerja dan berpenghasilan tidak lebih dari RM3,000 sebulan untuk memiliki rumah pertama mereka. Skim ini membolehkan golongan muda untuk mendapatkan pembiayaan sampai 100\% dari pembiayaan institusi-institusi keuangan untuk membeli rumah pertama tersebut, tanpa harus membayar uang muka 10\% (http://www.srp.com.my). 
Perbandingan selanjutnya adalah di negara Thailand harga rumah bersubsidi ditentukan oleh pemerintah, Rumah subsidi tersebut senilai dengan 390.000 Bath dan di peruntukan terhadap masyarakat dengan penghasilan kurang dari 18.000 Ribu Bath. Jangka waktu kredit sampai 30 tahun.(www.National Housing Autority. co.id.)

Pada Keputusan Menteri Perumahan Rakyat Nomor 3 Tahun 2014 tentang Fasilitas Likuiditas Pembiayaan Perumahan Melalui Kredit/Pembiayaan Pemilikan Rumah Sejahtera harga jual rumah sejahtera berdasarkan pada masing-masing wilayah provinsi. Sebagai contoh adalah harga jual rumah sejahtera di jawa tenggah menjadi Rp118,000,000,00 (Seratus Delapan Belas Juta Rupiah), dan diprovinsi DKI Jogjakarta adalah Rp123,000,000,00 (Seratus Dua Puluh Tiga Juta Rupiah), dan daerah Provinsi Jawa Timur adalah Rp115,000,000,00 (Seratus Lima Belas Juta Rupiah).

Berdasarkan Keputusan Menteri Perumahan Rakyat Nomor 3 Tahun 2014 tentang Fasilitas Likuiditas Pembiayaan Perumahan Melalui Kredit/Pembiayaan Pemilikan Rumah Sejahtera, Penerbitan KPR sejahtera tapak oleh bank pelaksana hanya dapat dilakukan paling lama tanggal 31 Maret 2015.

Dalam susunan kabinet Jokowi dan Jusuf Kalla, dari kementerian perumahan rakyat yang semula menteri Perumahan Rakyat digabungkan dengan kementerian pekerjaan umum menjadi kementerian pekerjaan umum dan perumahan rakyat. Dalam Peraturan Menteri Pekerjaan Umum dan Perumahan Rakyat Nomor 20/PRT/M/2015 tentang FLPP Dalam Rangka Perolehan Rumah Melalui Kredit/Pembiayaan Rumah Sejahtera Bagi Masyarakat Berpenghasilan Rendah, mencabut Permenpera sebelumnya termasuk pencabutan ketentuan pembiayaan rumah tapak sejehtera. Sehingga konsekuensinya pembiayaan rumah tapak sejahtera tetap diberikan pembiayaan melalui FLPP. 


\section{Simpulan}

1. Pemberian subsidi pada bidang perumahan merupakan salah satu kebijakan dari pemerintah terhadap penyediaan perumahan khususnya masyarakat berpenghasilan rendah. Dari koreksi harga pasar perumahan yang sangat tinggi tidak memberikan peluang kepada masyarakat berpenghasilan rendah untuk memiliki rumah. Pemberian subsidi terhadap masyarakat berpenghasilan rendah ini diharapkan akan mewujudkan masyarakat khususnya masyarakat berpenghasilan rendah untuk memiliki rumah.

2. Kendalayang menghambat pembangunan perumahan bersubsidi adalah rendahnya jumlah serapan perumahan bersubsidi apabila dibandingkan dengan semakin tingginya kebutuhan terhadap rumah.

\section{Daftar Pustaka}

Djauhari. 2006. Kajian Teori Welfare State dalam Prespektif Barat dan Islam. Jurnal Hukum. Vol XVI. No.1. UNISULA.Semarang .

Inosentius Samsul.2004.Perlindungan Konsumen (Kemungkinan Penerapan Tanggung Jawab Mutlak). FH Universitas Indonesia.

Koko Hernawan. 2011.Jual beli perumahan dengan dengan klausul eksonerasi, Perpustakaan UPN Surabaya

Y. Warella. Tanpa Tahun.Kepentingan Umum DAN Perorangan Perseorangan (ditinjau dari Aspek Publik). Eprints.undip.ac.id

Reinald Kasali. Kamis 10 Oktober 2013.Perumahan Rakyat,Jawa Pos

Kompas. Senin 26 Agustus 2013. bahwa bisnis perumahan masih tetap baik.Gramedia. Jakarta

Jawa Pos. Selasa 3 Januari 2012. Era Reformasi, ada 20 UU Yang Berbau Liberal" Jawa Pos

Kompas. Rublik Ekonomi “Investasi di Bidang Properti” Sabtu, 26 April 2014 http://elib.unikom.ac.id/files/disk1/511/jbptunikompp-gdl-anggitarac-25526-1-

babi.pdf

http://properti.kompas.com/read/2012/10/08/10155972/Akhirnya.Aturan.Rumah.S ubsidi.Direvisi. Diunduh pada Kamis, 26 Maret 2014. Jam 04.05 WIB http://bisnis.news.viva.co.id/news/read/357538-ingin-dapat-subsidi-rumahmungil--ini-Diunduh pada Kamis 26 Maret 2014. Jam 04.10 WIB 
http://finance.detik.com/read/2012/02/16/065221/1843675/1016/wuih-kebutuhanrumah-capai-26-juta-unit-per-tahun. Diunduh tgl 8 September 2013 jam 4.00.

Handa. S. Abidin. Definisi Masyarakat Berpenghasilan Rendah, Law Library of congres. http://penelitihukum.org/tag/definisi-masyarakat-berpenghasilan-

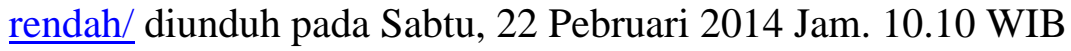

Skim Rumah Pertamaku. http://www.srp.com.my. Di unduh pada 2 April 2014 jam 04.15. WIB

www.National Housing Autority. co.id.Diunduh pada Jumat, 20 April 2014,jam 06.30 WIB

\section{Perundang-undangan}

Undang-Undang Dasar 1945

Undang-Undang Nomor 1 Tahun 2011 Tentang Perumahan dan Kawasan Permukiman.

Undang- Undang Nomor 25 Tahun 2000 tentang Program Pembangunan Nasional 2000-2004 (PROPERNAS)

Undang-Undang Nomor 28 tahun 2002 tentang Bangunan Gedung

Peraturan Menteri Negara Perumahan Rakyat RI Perumahan Rakyat Nomor 05 Tahun 2005 tentang Pengadaan Perumahan dan Permukiman Dengan Dukungan Fasilitas Subsidi Perumahan Melalui KPR/KPRS Bersubsidi.

Peraturan Menteri Perumahan Rakyat RI Nomor 02 Tahun 2006 tentang Pemberian Pinjaman/ Pembiayaan Uang Muka Kredit Kepemilikan Rumah (KPR) Bagi Pegawai Negeri Sipil.

Peraturan Menteri Perumahan Rakyat RI Nomor 12 Tahun 2006 tentang Perubahan Atas Peraturan Menteri Negara Perumahan Rakyat Nomor 05 Tahun 2005 tentang Pengadaan Perumahan dan Permukiman Dengan Dukungan Fasilitas Subsidi Perumahan Melalui KPR/KPRS Bersubsidi.

Peraturan Menteri Perumahan Rakyat RI Nomor 05 Tahun 2007 tentang Pengadaan Perumahan dan Permukiman Melalui KPRS/ KPRS Mikro Bersubdisi.

Peraturan Menteri Perumahan Rakyat RI Nomor 08 Tahun 2008 tentang Perubahan Atas PERMENPERA No. 04 Tahun 2007 Tentang Pengadaan Perumahan dan Permukiman Dengan Dukungan Fasilitas Subsidi Perumahan Melalui KPR Syariah Bersubsidi. 
Peraturan Menteri Negara Perumahan Rakyat Nomor 13 Tahun 2010 tentang Tata Cara Pelaksanaan KPR Bersubsidi dan KPR Syariah Bersubsidi.

Peraturan Menteri Negara Perumahan Rakyat RI Nomor 17 Tahun 2011 tentang

Tata Cara Pelaksanaan Subsisi Perumahan Melalui KPRS/ KPRS Mikro Bersubsidi.

Peraturan Menteri Negara Perumahan Rakyat RI Nomor 13 Tahun 2012 tentang Pengadaan Perumahan Melalui Kredit/ Pembiayaan Pemilikan Rumah Sejahtera dengan Dukungan Fasilitas Likuiditas Pembiayaan Perumahan.

Peraturan Menteri Perumahan Rakyat Nomor 3 Tahun 2014 tentang Fasilitas Likuiditas Pembiayaan Perumahan Melalui Kredit/ Pembiayaan Pemilikan Rumah Sejahtera.

Peraturan Menteri Perumahan Rakyat Nomor 5 Tahun 2014 tentang Proporsi Pendanaan Kredit/ Pembiayaan Pemilikan Rumah Sejahtera.

Peraturan Menteri Pekerjaan Umum dan Perumahan Rakyat Nomor 20/PRT/M/2015 tentang FLPP Dalam Rangka Perolehan Rumah Melalui Kredit/Pembiayaan Rumah Sejahtera Bagi Masyarakat Berpenghasilan Rendah 